\title{
Shear bond strength between resin cement and lithium disilicate ceramics after intrinsic staining
}

\author{
Resistência ao cisallhamento entre o cimento resinoso e o dissilicato de lítio após maquiagem
} intrínseca

Resistencia al cizallamiento entre el cemento de resina y las cerámicas de disilicato de litio después de la tinción intrínseca

Carla Kassis Pereira Cassiano

ORCID: https://orcid.org/0000-0003-3770-4258 Brazilian Dental Association, Brazil

E-mail: cakassis@hotmail.com

Sérgio Cândido Dias

ORCID: https://orcid.org/0000-0003-2570-2167 São Leopoldo Mandic School of Dentistry, Brazil

E-mail: cdsergiodias@gmail.com

Fernando Rigolin

ORCID: https://orcid.org/0000-0001-7112-1561

Private Practitioner, Brazil

E-mail: ferrigolin@uol.com.br

Rogério Luiz de Oliveira Mussel

ORCID: https://orcid.org/0000-0002-3895-7620

Private Practitioner, Brazil

E-mail: rmussel@gmail.com

Leandro Medeiros dos Santos

ORCID: https://orcid.org/0000-0003-4928-2881

Arnaldo Jansen Dental School, Brazil

E-mail: leandromedeiros@gmail.com

Rodrigo Tiossi

ORCID: https://orcid.org/0000-0001-5781-9760

State University of Londrina, Brazil

E-mail: rtiossi@uel.br

\begin{abstract}
Shear bond strength between resin cement and lithium disilicate ceramics after different etching protocols, different heat treatments, and intrinsic staining was tested. Lithium disilicate specimens were $10 \mathrm{~mm}$ long by $5 \mathrm{~mm}$ wide by 2 $\mathrm{mm}$ thick and were divided into 5 groups $(\mathrm{n}=10)$ : Group 1: specimens heated to $840^{\circ} \mathrm{C}$; Group 2: specimens submitted to double heating treatment (heated to $840^{\circ} \mathrm{C}$, cooled down, heated to $770{ }^{\circ} \mathrm{C}$ ); Group 3: specimens heated to $840{ }^{\circ} \mathrm{C}$, cooled down, intrinsically stained, heated to $770{ }^{\circ} \mathrm{C}$; Group 4 : specimens heated to $840{ }^{\circ} \mathrm{C}$, cooled down, heated to 800 ${ }^{\circ} \mathrm{C}$; Group 5: specimens heated to $840^{\circ} \mathrm{C}$, cooled down, intrinsically stained, heated to $800{ }^{\circ} \mathrm{C}$. Groups 1,3 , and 5 were etched with $10 \%$ hydrofluoric acid (HF) and analyzed by scanning electron microscopy (SEM) at 10,000×. Specimens from groups 2 and 4 were not etched with HF. Energy dispersive spectrometry (EDS) and SEM analyzed specimen staining physicochemical changes in groups 3 and 5 . The resin cement samples were $1-\mathrm{mm}$ in diameter and 2-mm in height. Analysis of variance and independent $t$ test were used to compare the groups in the study $(p<0.05)$. Different lithium disilicate surface and heat treatments changed specimen topography. No significant effect was found in the adhesion between intrinsically stained lithium disilicate specimens and resin cement $(\mathrm{p}>0.05)$. Shear bond strength between resin cement and lithium disilicate ceramics was not influenced by intrinsic staining. Topography of the ceramic material changed with different heating temperatures and with acid etching.
\end{abstract}

Keywords: Adhesives; Ceramics; Shear strength.

\section{Resumo}

O objetivo deste estudo foi avaliar através de ensaio de resistência de união de microcisalhamento e verificação por microscopia eletrônica de varredura, a influência do acréscimo de maquiagem intrínseca em cerâmicas. Foram utilizadas placas de cerâmicas a base de dissilicatao de lítio nas dimensões de $10 \mathrm{~mm}$ x $5 \mathrm{~mm}$ x $2 \mathrm{~mm}$. As cerâmicas foram divididas em 5 grupos: Grupo 1 cristalizadas a $840{ }^{\circ} \mathrm{C}$; Grupo 2 cristalizadas a $840{ }^{\circ} \mathrm{C}$ e queimadas a $770{ }^{\circ} \mathrm{C}$; Grupo 3 cristalizadas a $8400^{\circ} \mathrm{C}$ maquiadas e queimadas a $770{ }^{\circ} \mathrm{C}$, Grupo 4 : foram cristalizadas a $840{ }^{\circ} \mathrm{C}$ e queimadas a $800{ }^{\circ} \mathrm{C}$, 
Grupo 5: foram cristalizadas a $840{ }^{\circ} \mathrm{C}$ maquiadas e queimadas a $800{ }^{\circ} \mathrm{C}$. Os grupos 1,3 e 5 foram analisadas por microscopia eletrônica de varredura (MEV) analisando o tratamento com ácido fluorídrico na concentração de $10 \%$. Os grupos 3 e 5 foram analisadas por MEV-EDS para a análise de espectrometria por energia dispersiva para avaliar a composição química da maquiagem. Os espécimes possuíam dimensões de $1,0 \mathrm{~mm}$ de diâmetro e $2 \mathrm{~mm}$ de altura para confecção dos espécimes em cimento resinoso fotoativado. As análises dos dados foram realizadas através da Análise de Variância (2 fatores) e teste de T ( $<<0,05)$. Os tratamentos modificaram a topografia das superfícies cerâmicas. Não foram encontradas alterações significantes na adesão entre o dissilicato de lítio após a maquiagem intrínseca e o cimento resinoso $(p>0,05)$. A resistência ao cisalhamento entre o cimento resinoso e o dissilicato de lítio não foi influenciada pela maquiagem intrínseca. Os diferentes tratamentos de superfície alteraram a topografia do material cerâmico.

Palavras-chave: Adesivos; Cerâmica; Resistência ao cisalhamento.

\section{Resumen}

El objetivo de este estudio fue evaluar através de un ensayo de resistencia de unión de microcizallamiento y verificación con microoscopia electrónica de barrido, la influencia del agregado de maquillaje intrínseco en cerámicas. Fueron utilizadas placas de cerámica a base de disilicato de litio con dimensiones de $10 \mathrm{~mm}$ x $5 \mathrm{~mm}$ x $2 \mathrm{~mm}$. Las cerámicas fueron divididas en 5 grupos: Grupo 1 cristallzadas a 840 C; Grupo 2 cristalizadas a 840 C y quemadas a 770 C; Grupo 3 cristalizadas a $840 \mathrm{C}$, maquilladas y quemadas a $770 \mathrm{C}$; Grupo 4 fueron cristalizadas a $840 \mathrm{C}$ y quemadas a $800 \mathrm{C}$, Grupo 5 fueron cristalizadas a $840 \mathrm{C}$, maquilladas y quemadas a $800 \mathrm{C}$. Los grupos 1, 3 y 5 fueron analizados por microscopía electrónica de barrido (MEV) analizando el tratamiento con ácido fluorhídrico con concentración de $10 \%$. Los grupos 3 y 5 fueron analizados por MEV-EDS para el análisis de espectometria por energía dispersiva para evaluar la composición química del maquillaje. Los especímenes poseían dimensiones de 1,0 mm de diámetro y 2 mm de altura para la confección de los especímenes en cemento resinoso fotoactivado. El análisis de los datos fue realizado a través del análisis de varíanza ( 2 factores) y la prueba de $\mathrm{T}(\mathrm{p}<0,05)$. Los tratamientos modificaron la topografía de las superficies cerámicas. No fueron encontradas alteraciones significantes en la adhesión entre el disilicato de litio después del maquillaje intrinseco y el cemento resinoso $(\mathrm{p}<0,05)$. La resistencia al cizallamiento entre el cemento resinoso y el disilicato de litio no fue influenciada por el maquillaje intrínseco. Los diferentes tratamientos de superficie alteraron la topografía del material cerámico.

Palabras clave: Adhesivos; Cerámica; Resistencia al corte.

\section{Introduction}

1Mimicking the optical properties of natural teeth with artificial materials is among the greatest challenges in dentistry (O'Brien 1985; Li et al. 2009). The perceived color for the final ceramic restoration is influenced by factors that include ceramic thickness, color and opacity of the luting agent, and color of the remaining tooth structure (Niu et al. 2014). Light transmission through the restoration improves the esthetics of pure ceramics (Al Ben Ali et al. 2014). However, color differences in the remaining tooth structure could compromise the final esthetic outcome of the restoration. Some operative and laboratorial techniques could effectively mask the underlying substrate such as increased tooth preparation to allow for thicker restorations, use of less translucent ceramics, and selection of more opaque luting agents (Niu et al. 2014).

The bonded interface between glass ceramics and resin cements plays an important role in the long-term reliability of ceramic restorations. Pretreatment with hydrofluoric acid (HF) followed by silanization are among the most widely used surface treatments for glass ceramics (Faria et al. 2021). The complex environment of the oral cavity with temperature change, presence of saliva, biting force, and daily food and drink intake are among the different factors that directly influence the ceramic and resin bond (Tian et al. 2014).

Traditional methods to fabricate ceramic restorations are time consuming, technique sensitive, and somewhat unpredictable due several influencing factors that include experience of the dental technician. Computer-aided design and computer-aided manufacturing (CAD/CAM) technology is a good alternative for both dental technicians and clinicians. $\mathrm{CAD} / \mathrm{CAM}$ could reduce the time needed for restoration fabrication, the prefabricated ceramic blocks are more homogeneous with minimal flaws, and the restorations are favorably compared with conventional ceramic restorations, with high longevity for monolithic crowns (Li et al. 2014; Sulaiman et al. 2015).

When adhesively luted, lithium disilicate glass ceramics have shown adequate fracture strength, color stability, and translucency similar to that of natural teeth ( $\mathrm{Li}$ et al. 2014). The recommended staining technique for lithium disilicate ceramics 
should be performed along with the crystallization process or at a separate procedure. Extrinsically stained ceramics could lose surface integrity and present increased surface roughness with toothbrushing (Bativala et al. 1987). Such factors could be minimized with the use of an intrinsic staining technique. However, it is unclear whether an experimental intrinsic staining technique could influence the bonding between the ceramic material and the luting agent.

This in vitro quantitative (Pereira et al. 2018) study tested the shear bond strength between resin cement and lithium disilicate ceramics after different etching protocols, different heat treatments, and intrinsic staining. The surface characteristics of the ceramic material after the different treatment protocols were also analyzed. The tested hull hypothesis was that the different ceramics treatment protocols would not significantly influence bonding with the luting agent nor the ceramic material surface characteristics.

\section{Methodology}

Fifteen prefabricated lithium disilicate blocks (IPS e.max CAD, Ivoclar Vivadent, Schaan, Liechtenstein, Germany) were used to fabricate 50 specimens with $10 \mathrm{~mm}$ in length by $5 \mathrm{~mm}$ in width by $2 \mathrm{~mm}$ in thickness. Specimens were cut by using double-faced diamond discs in a precision sectioning saw (Isomet 1000, Buehler Ltd, Lake Bluff, Illinois, USA) under constant cooling. Surfaces of the specimens were manually polished by the same operator using abrasive papers with crescent grits as follows: 100, 400, 600, 1200, 2000. All specimens were then ultrasonically cleaned (Ultrasound bath Cristófoli 2.51, Cristófoli Equipamentos de Biossegurança LTDA, Campo Mourão, Brazil) in distilled water for 5 minutes.

Specimens were crystallized in a dental porcelain furnace (Ivoclar EP 5000, Ivoclar Vivadent, Schaan, Liechtenstein, Germany) according to firing instructions from the manufacturer of the lithium disilicate blocks (Ivoclar Vivadent). Specimens from groups 3 and 5 were stained (Vanille Empress, Ivoclar Vivadent) after the first firing cycle and then submitted to a second firing cycle. Groups 2 and 4 were submitted to 2 firing cycles without the intrinsic staining procedure (Control groups). Figure 1 shows the specimens without and with the intrinsic staining procedure, respectively. Experimental heating temperatures were used for groups 4 and 5 in the second firing cycle. Table 1 describes each group in the study ( $\mathrm{n}=10$ ) and shows the different heat treatments that were used.

Figure 1. Lithium disilicate specimens without and with intrinsic staining, respectively.

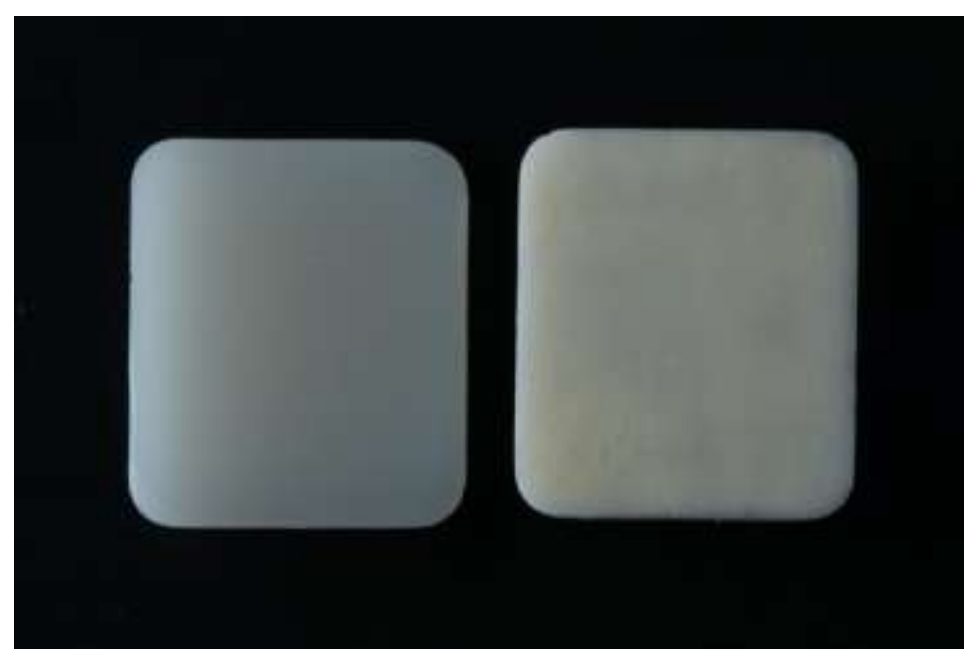

Source: Authors. 
Table 1. Heat treatments and intrinsic staining used for each group in the study.

\begin{tabular}{lll}
\hline Groups & First firing cycle & Second firing cycle \\
\hline Group 1 & Crystallized at $840{ }^{\circ} \mathrm{C}$ & \\
\hline Group 2 & Crystallized at $840^{\circ} \mathrm{C}$ & Heated to $770{ }^{\circ} \mathrm{C}$ \\
\hline Group 3 & Crystallized at $840{ }^{\circ} \mathrm{C}$ & Stained + Heated to $770{ }^{\circ} \mathrm{C}$ \\
\hline Group 4 & Crystallized at $840{ }^{\circ} \mathrm{C}$ & Heated to $800{ }^{\circ} \mathrm{C}$ \\
\hline Group 5 & Crystallized at $840{ }^{\circ} \mathrm{C}$ & Stained + Heated to $800{ }^{\circ} \mathrm{C}$ \\
\hline
\end{tabular}

Source: Authors.

All specimens were included in polyvinyl chloride (PVC) pipes with polystyrene resin (Aerojet, Santo Amaro, SP, Brazil) with their stained or polished surfaces protected by double-sided tape (Figure 2, A-C). Hydrofluoric acid (HF) at 10\% (Porcelain conditioner, Dentsply, York, PA, USA) was then applied to the surface of each specimen for 20 seconds according to instructions from the manufacturer. All specimens were washed with running water for 60 seconds and then ultrasonically cleaned under distilled water for 5 minutes with their treated surfaces facing down. The specimens were dried with oil-free air for 15 seconds. Silane coupling agent (Monobond Plus Ivoclar Vivadent, Schaan, Liechtenstein, Germany) was applied to the treated surfaces with disposable applicators (Microbrush, Microbrush Corporation, Grafton, WI, USA) for 60 seconds and then air-dried for 15 seconds. Adhesive (Scothbond, 3M ESPE, Minnesota, USA) was applied on the treated specimen surface, airdried for 5 seconds, and light-polymerized (Bluephase, Ivoclar Vivadent, Schaan, Liechtenstein, Germany) for 40 seconds. 
Figure 2. A - Cut polyvinyl chloride tubes before specimen inclusion; B - Polyvinyl chloride tubes after polystyrene resin insertion; C - Polyvinyl chloride tubes after specimen inclusion.
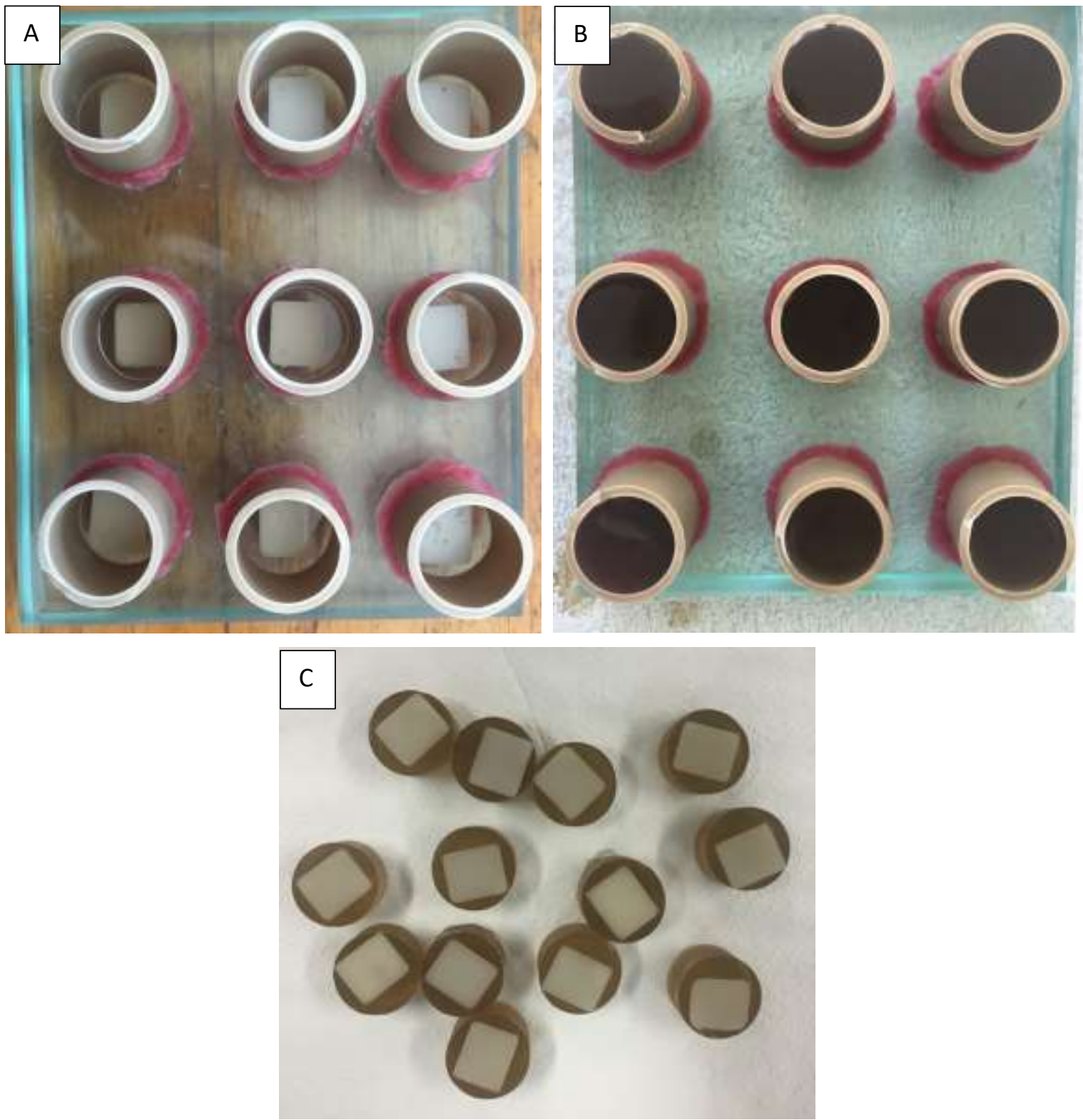

Source: Authors.

A polyvinylsiloxane matrix (Express XT, 3M, ESPE, Minnesota, USA) was fabricated with a $2 \mathrm{~mm}$ high by $1 \mathrm{~mm}$ wide perforation to insert the resin cement (Variolink Esthetic, Ivoclar Vivadent, Schaan, Liechtenstein, Germany). Each sample was photopolymerized for 30 seconds, removed from the matrix, and photopolymerized for 20 seconds. Each lithium disilicate specimen in the study had 2 resin cement cylinders luted to their surfaces (Figure 3, A and B) thus accounting for 20 shear strength bonding tests for each group. All specimens were then stored in a furnace at $37{ }^{\circ} \mathrm{C}$ for 24 hours. 
Figure 3. A - Resin cement samples luted to the lithium disilicate specimens; B - Resin cement samples with $1 \mathrm{~mm}$ diameter.
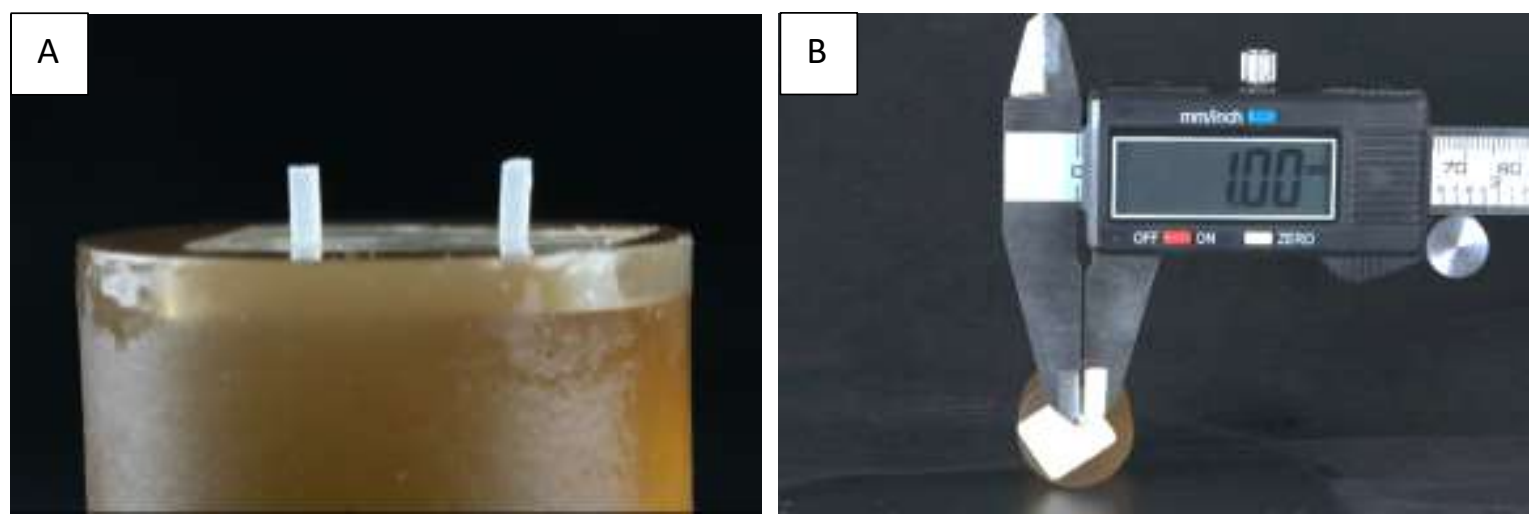

Source: Authors.

Shear strength tests were performed in a universal testing machine (EZ-LX Long-Stroke, Shimadzu, Kyoto, Japan) with a $0.2 \mathrm{~mm}$ diameter stainless steel archwire at crosshead speed of $0.5 \mathrm{~mm} / \mathrm{min}$ speed and $5 \mathrm{~kg} / \mathrm{N}$ force until fracture (Figure 4 , A and B). Maximum failure load was recorded in Newtons (N) and converted to MPa by dividing the failure load by the bonding area $\left(\mathrm{mm}^{2}\right)$.(Bitter et al. 2006) All fractured specimens were gold sputtered (Denton Desk II/ Denton Vacuum LLC, Moorestown, NJ, USA) for the scanning electron microscopy (SEM) analysis (JSM 5600LV, JEOL, Tokyo, Japan). Failure modes were classified as follows: Type 1: adhesive failure between bonded surface and cement; Type 2: cohesive failure inside ceramics, staining, or resin cement; and Type 3: mixed combination of both failure types. 
Figure 4. A - Universal testing machine setup to perform the shear strength tests; B - Stainless steel archwire connected to a resin cement sample.

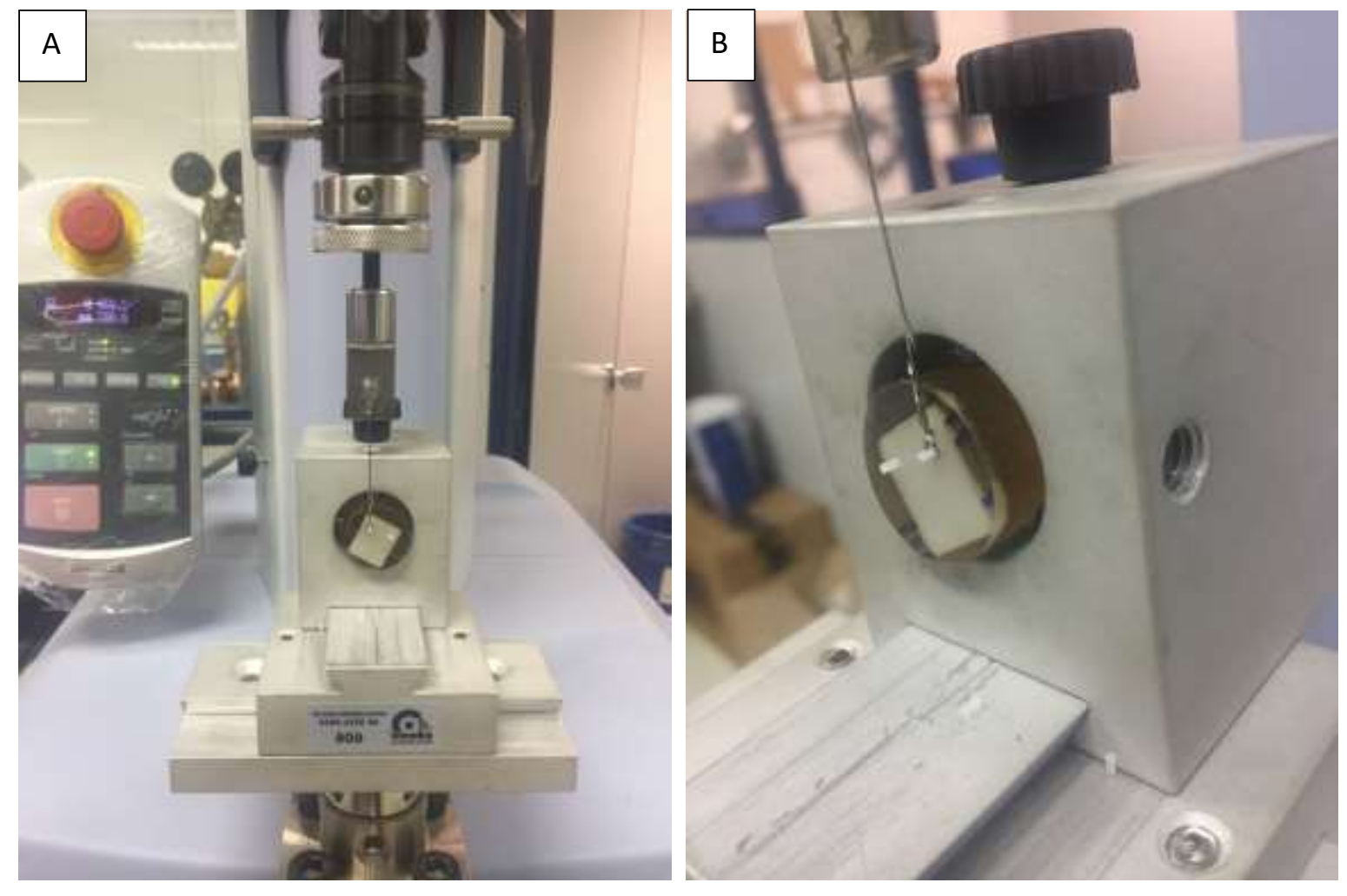

Source: Authors.

The surface topography of lithium disilicate ceramics was analyzed by SEM before and after $10 \%$ HF etching. Two specimens from groups 1,3, and 5 (standard and both intrinsic stained groups, respectively) were used to analyze surface topography. One specimen from each selected group was conditioned with $10 \% \mathrm{HF}$ and the other remained unconditioned. Specimens were then analyzed by SEM at $10,000 \times$ to check for topography pattern modifications after HF conditioning. Energy dispersive spectrometry (EDS) was used to determine the chemical composition of two specimens from groups 3 and 5 (intrinsically stained groups) without HF surface conditioning. Each specimen was analyzed on 4 spots and the average percentage of each chemical component was detected.

Two-way analysis of variance (ANOVA) was used to statistically compare the shear bond strength of the groups in the study with the aid of specialized software (GraphPad Prism 6.0, La Jolla, CA, USA) $(\mathrm{p}<0.05)$.

\section{Results}

Shear bond strength results and statistical comparison between groups are shown in Table 2. No significant differences were found between the groups in the study $(\mathrm{p}>0.05)$. Table 3 presents the percentage of failure mode types found for each group. Adhesive failure was mostly found for groups 2, 4, and 5 whereas group 1 showed more of a mixed adhesive and cohesive failure mode and group 3 had more cohesive failure inside the intrinsic staining. 
Table 2. Shear bond strength, standard deviation (SD), and t test results found in the study.

\begin{tabular}{cccccc}
\hline & Group 1 & Group 2 & Group 3 & Group 4 & Group 5 \\
\hline Mean \pm SD & $11.62 \pm 1.96$ & $11.06 \pm 3.08$ & $10.89 \pm 2.48$ & $11.10 \pm 3.12$ & $9.04 \pm 3.60$ \\
\hline t test* $^{*}$ & $\mathrm{~A}$ & $\mathrm{~A}$ & $\mathrm{~A}$ & $\mathrm{~A}$ & $\mathrm{~A}$ \\
\hline
\end{tabular}

*Groups connected by the same letter showed no significant differences ( $>0.05)$. Source: Authors.

Table 3. Failure mode percentage for each group.

\begin{tabular}{|c|c|c|c|c|}
\hline Groups & Adhesive failure & $\begin{array}{c}\text { Cohesive failure inside } \\
\text { resin cement }\end{array}$ & $\begin{array}{l}\text { Cohesive failure inside } \\
\text { intrinsic staining }\end{array}$ & $\begin{array}{c}\text { Mixed adhesive and } \\
\text { cohesive failure }\end{array}$ \\
\hline Group 1 & $40 \%$ & $5 \%$ & 0 & $55 \%$ \\
\hline Group 2 & $60 \%$ & $35 \%$ & 0 & $5 \%$ \\
\hline Group 3 & $25 \%$ & $20 \%$ & $50 \%$ & $5 \%$ \\
\hline Group 4 & $70 \%$ & $10 \%$ & 0 & $20 \%$ \\
\hline Group 5 & $80 \%$ & 0 & $15 \%$ & $5 \%$ \\
\hline
\end{tabular}

Source: Authors.

The SEM scans of groups 1, 3, and 5 with and without $10 \% \mathrm{HF}$ surface conditioning are presented in figure 5, A-F. It was found that acid etching with $10 \%$ HF exposed lithium disilicate crystals in group 1 by removing some of the silicon component (Figure 5, A and B). The surface aspect changed with the different heating temperatures used in the second firing cycle for groups 3 and 5 (Figure 5, C-F). The EDS analysis found no significant differences on the chemical composition between the 2 groups with different heat treatments ( 3 and 5) that were analyzed. The basic chemical components for both groups were Oxygen, Silicon, Calcium, Aluminum, Potassium, and Carbon, with a prevalence of Oxygen (45.95\% for group 3 and $46.75 \%$ for group 5) and Silicon (25.95\% for group 3 and $25.49 \%$ for group 5). 
Figure 5. A - SEM image of group 1 without 10\% HF surface conditioning; B - SEM image of group 1 with 10\% HF surface conditioning; C - SEM image of group 3 without 10\% HF surface conditioning; D - SEM image of group 3 with 10\% HF surface conditioning; $\mathbf{E}$ - SEM image of group 5 without $10 \% \mathrm{HF}$ surface conditioning; F - SEM image of group 5 with $10 \%$ HF surface conditioning.
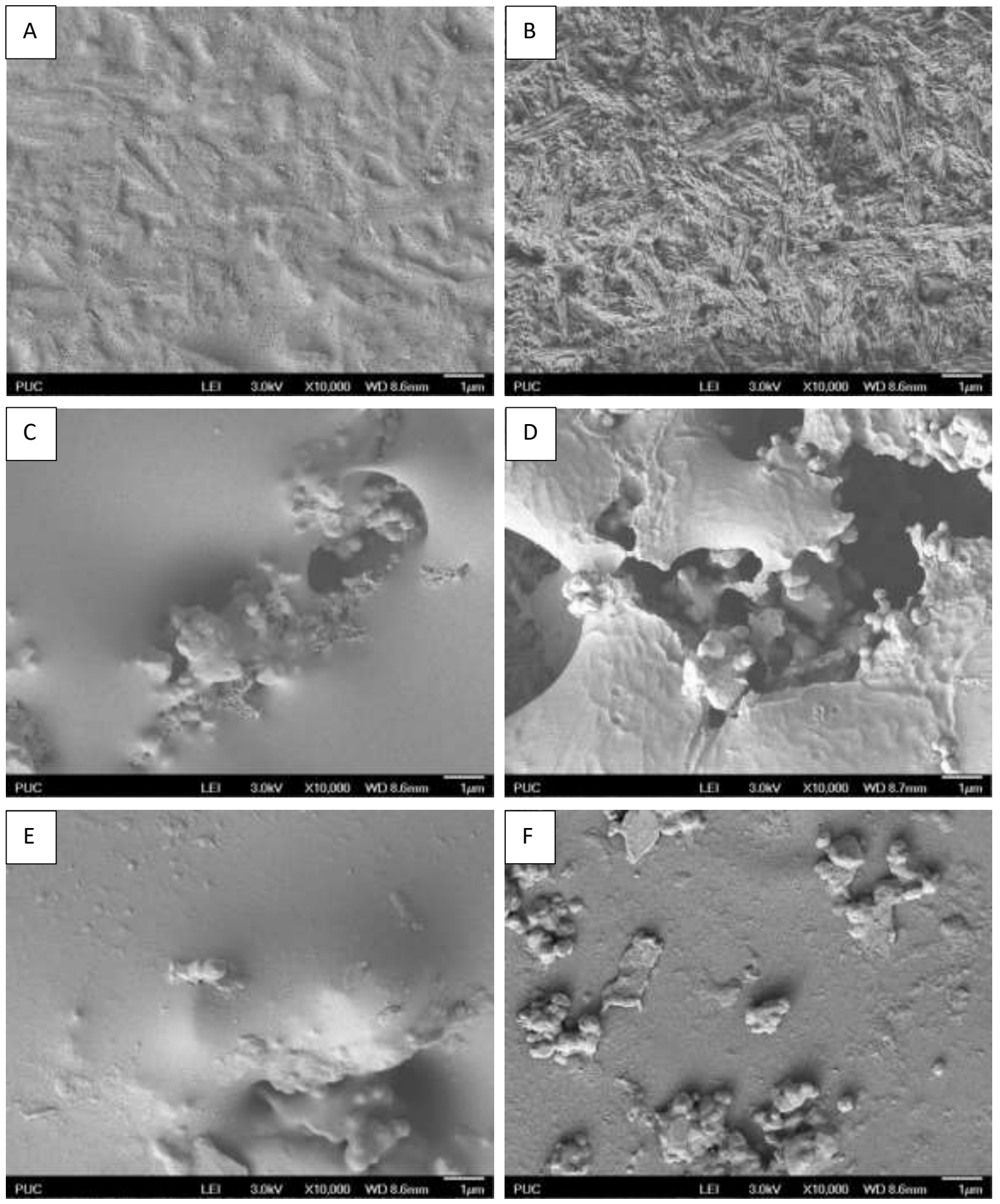

Source: Authors. 


\section{Discussion}

Shear bond strength between resin cement and lithium disilicate ceramics was tested after different etching protocols, different heat treatments, and intrinsic staining. The results support partial acceptance of the tested hull hypothesis since the different ceramic treatment protocols had no significant influence in the bonding with the luting agent. However, topography of the ceramic material was changed with different heating temperatures that were tested and when acid etching was performed.

The use of monolithic crowns have increased due to its high fracture strength (Sulaiman et al. 2015). Monolithic crowns are often CAD/CAM fabricated for later shading and staining to achieve the final restoration color (Culp \& McLaren 2010; Pieger et al. 2014). The staining method for lithium disilicate ceramic material tested in this study can be performed during the crystallization process or at a second firing cycle, as was used in this study. Surface integrity of extrinsically stained ceramics was lost after 11.4 years brushing simulation (Bativala et al. 1987). Another study (Garza et al. 2016) reported that extrinsic staining is significantly affected by toothbrushing time due direct exposure to the oral environment. Material color wear could be minimized by the intrinsic staining technique.

This study found no significant influence in the shear bond strength of a second firing cycle after lithium disilicate crystallization. This is in agreement with an earlier study (Yuan et al. 2013) that tested the effect of different sintering times in the flexural strength and translucency of lithium disilicate ceramics and found similar crystal structure despite repetitive sintering processes. Adhesion between the restorative material, the luting agent, and the dental structure is both chemical and mechanical (Saracoglu et al. 2004). Surface conditioning with HF and a silane coupling agent are commonly used for luting ceramic restorations with resin cement and the dental structure. Bonding between the silica oxides present in ceramics surface and the resin cement is achieved by silane coupling agents by means of siloxane bonds (Brentel et al. 2007). This could have influenced the results found in this study since the most present chemical components in the intrinsically stained surface were Oxygen and Silicon, thus suggesting an increased presence of Silicon dioxide $\left(\mathrm{SiO}_{2}\right)$ that favored shear bond strength.

Acid etching with $10 \%$ HF selectively removes the glassy matrix thus exposing the lithium disilicate crystals, which is in agreement with the SEM images found in this study for group 1 (Blatz et al. 2003). The intrinsic staining of specimens from group 3 was partially removed, thus limiting the identification whether it was properly conditioned. This finding could have contributed with the higher prevalence of cohesive failures inside the intrinsic staining that was found for this group. Topography of group 5 was similar with and without acid etching with $10 \% \mathrm{HF}$, which probably contributed to the higher presence of adhesive failures.

Intrinsic staining had no significant effect in the shear bond strength, irrespective of the heating temperature used in the second firing cycle. However, a $17 \%$ decrease in the shear bond strength was found when the specimens were heated to $800{ }^{\circ} \mathrm{C}$ (Group 5). Adhesive failure occurred in most of the specimens that were tested. The reduced bonding area $\left(1 \mathrm{~mm}^{2}\right)$ between resin cement and lithium disilicate could lead to concentrated forces in this region, thus resulting in the prevalence of adhesive failures.

\section{Final Considerations}

Shear bond strength between resin cement and lithium disilicate ceramics was not influenced by the intrinsic staining. Topography of the ceramic material was changed with different heating temperatures and with acid etching. Silicon and oxygen were the most prevalent chemical elements that were found in the lithium disilicate ceramics surface. Further aging-simulation and clinical studies are recommended to evaluate the stability, color, esthetics, and longevity of intrinsically stained lithium disilicate restorations. The consequences of multiple firing cycles in the restoration staining could also be evaluated in future studies. 
Research, Society and Development, v. 10, n. 3, e6410313035, 2021

(CC BY 4.0) | ISSN 2525-3409 | DOI: http://dx.doi.org/10.33448/rsd-v10i3.13035

\section{References}

Al Ben Ali, A., Kang, K., Finkelman, M. D., Zandparsa, R., \& Hirayama, H. (2014). The effect of variations in translucency and background on color differences in CAD/CAM lithium disilicate glass ceramics. J Prosthodont, 23(3), 213-220.

Bativala, F., Weiner, S., Berendsen, P., Vincent, G. R., Ianzano, J., \& Harris, W. T., Jr. (1987). The microscopic appearance and effect of toothbrushing on extrinsically stained metal-ceramic restorations. J Prosthet Dent, 57(1), 47-52.

Bitter, K., Paris, S., Hartwig, C., Neumann, K., \& Kielbassa, A. M. (2006). Shear bond strengths of different substrates bonded to lithium disilicate ceramics. Dent Mater J, 25(3), 493-502.

Blatz, M. B., Sadan, A., \& Kern, M. (2003). Resin-ceramic bonding: a review of the literature. J Prosthet Dent, 89(3), $268-274$.

Brentel, A. S., Ozcan, M., Valandro, L. F., Alarca, L. G., Amaral, R., \& Bottino, M. A. (2007). Microtensile bond strength of a resin cement to feldpathic ceramic after different etching and silanization regimens in dry and aged conditions. Dent Mater, 23(11), 1323-1331.

Culp, L., \& McLaren, E. A. (2010). Lithium disilicate: the restorative material of multiple options. Compend Contin Educ Dent, 31(9), 716-720, 722, 724-715.

Faria, L. F. de., Cardoso, M. S., Lima, C. M., Melo, L. A. de., \& Leite, F. P. P. (2021). Influence of hydrofluoric acid etching time on the prosthetic adhesion of vitreous ceramics: a systematic review. Research, Society and Development, 10(2), e18810212240.

Garza, L. A., Thompson, G., Cho, S. H., \& Berzins, D. W. (2016). Effect of toothbrushing on shade and surface roughness of extrinsically stained pressable ceramics. J Prosthet Dent, 115(4), 489-494.

Li, Q., Yu, H., \& Wang, Y. N. (2009). Spectrophotometric evaluation of the optical influence of core build-up composites on all-ceramic materials. Dent Mater, 25(2), 158-165.

Li, R. W., Chow, T. W., \& Matinlinna, J. P. (2014). Ceramic dental biomaterials and CAD/CAM technology: state of the art. J Prosthodont Res, 58(4), 208-216.

Niu, E., Agustin, M., \& Douglas, R. D. (2014). Color match of machinable lithium disilicate ceramics: Effects of cement color and thickness. J Prosthet Dent, $111(1), 42-50$.

O'Brien, W. J. (1985). Double layer effect and other optical phenomena related to esthetics. Dent Clin North Am, 29(4), 667-672.

Pereira, A. S., Shitsuka, D. M., Parreira, F. J., \& Shitsuka, R. (2018). Metodologia da pesquisa científica. Santa Maria: Ed. UAB / NTE / UFSM.

Pieger, S., Salman, A., \& Bidra, A. S. (2014). Clinical outcomes of lithium disilicate single crowns and partial fixed dental prostheses: a systematic review. $J$ Prosthet Dent, 112(1), 22-30.

Saracoglu, A., Cura, C., \& Cotert, H. S. (2004). Effect of various surface treatment methods on the bond strength of the heat-pressed ceramic samples. J Oral Rehabil, 31(8), 790-797.

Sulaiman, T. A., Delgado, A. J., \& Donovan, T. E. (2015). Survival rate of lithium disilicate restorations at 4 years: A retrospective study. J Prosthet Dent, 114(3), 364-366.

Tian, T., Tsoi, J. K., Matinlinna, J. P., \& Burrow, M. F. (2014). Aspects of bonding between resin luting cements and glass ceramic materials. Dent Mater, 30(7), e147-162.

Yuan, K., Wang, F., Gao, J., Sun, X., Deng, Z., Wang, H., \& Chen, J. (2013). Effect of sintering time on the microstructure, flexural strength and translucency of lithium disilicate glass-ceramics. Journal of Non-Crystalline Solids, 362(7-13. 